https://www.journal-imab-bg.org

Original article

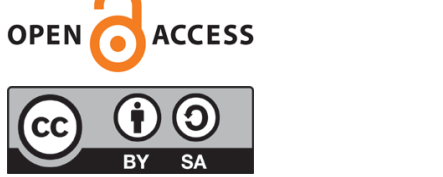

\title{
INFLUENCE OF CROWN HEIGHT SPACE IN CASES OF DETACHMENT OF THE IMPLANT SUPPORTED FIXED PARTIAL DENTURES: RET- ROSPECTIVE CLINICAL STUDY.
}

\author{
Dimitar Kirov ${ }^{1}$, Biser Stoichkov ${ }^{2}$ \\ 1) Department of Prosthetic Dentistry, Faculty of Dental Medicine, Medical \\ University, Sofia, Bulgaria. \\ 2) Department of Oral and Maxillofacial Surgery, Faculty of Dental Medi- \\ cine, Medical University, Sofia, Bulgaria.
}

\section{SUMMARY:}

Aim of the study: The purpose of the current study was to determine the influence of the crown height space on the loss of retention in different types of implant-supported Fixed Partial Dentures (FPD).

Material and Methods: 116 patients being partially edentulous regarding maxilla and mandibula have been followed retrospectively and restored by means of fixed prostheses on 261 implants. The study covered a five-year follow-up. The following indicators have been traced: implantation area, type of prosthetic restorations (single crowns, splinted crowns, bridge implant - implant, bridge implant - natural tooth), the height of restorative space and detachment of prosthetic restorations.

Results: The detachment of the prosthesis was found in $5.7 \%$ of all cases. This was most frequently seen in the mandibular molar area $(73.33 \%)$ when single crown restorations were used. The incidence of loss of retention increased when the crown height space was less than $8.0 \mathrm{~mm}$. The conducted tests showed that these indicators affect with statistical significance.

Conclusion: The results of the current study give us grounds for assuming that the reduced crown height space, the places of implantation and the type of restorations are important prerequisites for the occurrence of prosthetic restorations detachment.

Keywords: crown height space, detachment of FPD, dental implant complications, implant supported FPD

\section{INTRODUCTION}

Retaining of the fixed implant-supported restorations is accomplished in several ways - by means of adhesion (cementing), screwing or by a combination of both [1]. Their advantages and disadvantages, as well as their influence on the frequency of mechanical and biological complications $[2,3]$, have been widely discussed in the scientific literature.

Mechanical complications in fixed implant-supported prostheses can be difficult to correct, particularly when they are permanently cemented. Loss of retention between the abutment and prosthetic restoration is one of the most common complications associated with the long-term function of fixed implant restorations.

The results of the detachment researches of fixed implant prostheses are heterogeneous and show a frequency of such complication from 2.0 to $12.5 \%$ within the first five years. The risk of loss of retention after the fifth year increases to $23.72 \%$ [4-8].

For the construction of the fixed implant supported restorations having high aesthetic and functional characteristics, the height of the restorative space is supposed to be within an optimal range. It has been found out that the most favourable height for making fixed implant restorations is between 8 and $12 \mathrm{~mm}[9,10]$. This has an influence on the stability of such restorations for the years to come. The loss of adhesive retention is most often established when the height of prosthetic restoration is less than $6 \mathrm{~mm}[11,12]$. In such cases, the shorter abutment cannot provide adequate retention of prosthetic restorations [13].

On the other hand, the type of restoration has a significant impact on the onset of detachment in fixed implant supported restorations. Data from the studies of Clelland $\mathrm{N}$ et al. and of Pellizzer EP et al. shows that the incidence of mechanical complications is lower in making dentures with splinted crowns compared to those with single crowns under similar other conditions $[14,15]$.

According to other authors, the use of splinted crowns leads to a reduced incidence of failed implant treatment [16].

The biomechanical impact analyses in the study of bridges of the implant - natural tooth type are contradictory. The occurrence of mechanical complications is more often described, and the detachment of the fixed prosthesis turns out to be most frequent among them [17-20].

The aim of this study was to determine the influence of the crown height space on the loss of retention in different types of implant-supported Fixed Partial Dentures (FPD). 


\section{MATERIAL AND METHODS}

In the present study, 116 patients being partially edentulous regarding upper and lower jaws - 63 women and 55 men were followed retrospectively. The treatment was performed with fixed restorations on 261 implant supports. Two-stage late implantation was used following open surgical procedures (Fig 1-1 and Fig 1-2).

Fig. 1-1. Subcrestal implant placement by flap surgery with a minimum elevation of the soft tissues.



Fig. 1-2. Closure of the surgical wound.



The age of the study group is from 15 to 78 years. The dental implants were exposed after four months of implantation in the lower jaw and after six months in the upper jaw (Fig 2-1 and Fig 2-2).
Fig. 2-1. Second surgical stage: Dental implant uncovering by forming a mucoperiosteal flap and removing the cover screw. Six months after implantation.

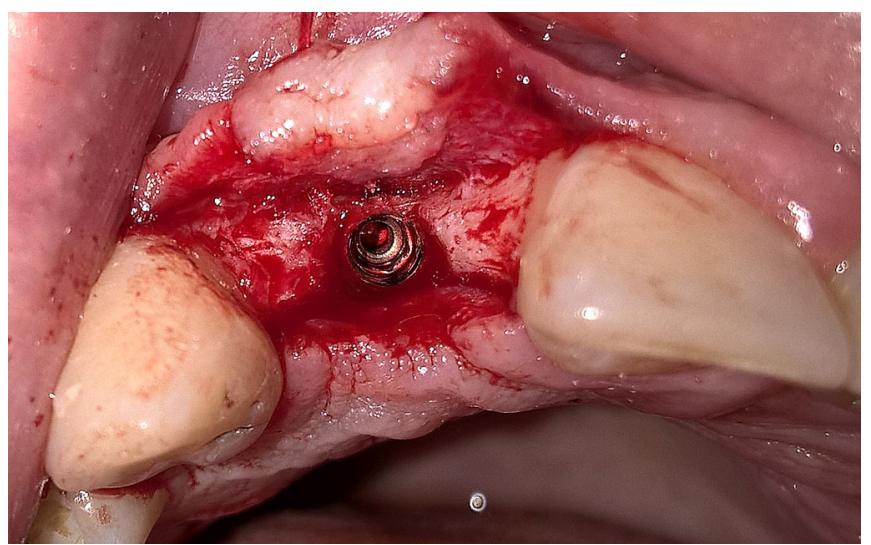

Fig. 2-2. Second surgical stage: placement of healing abutment and tissue suturing. The time required for healing and shaping gingival tissues is between 2 and 3 weeks.

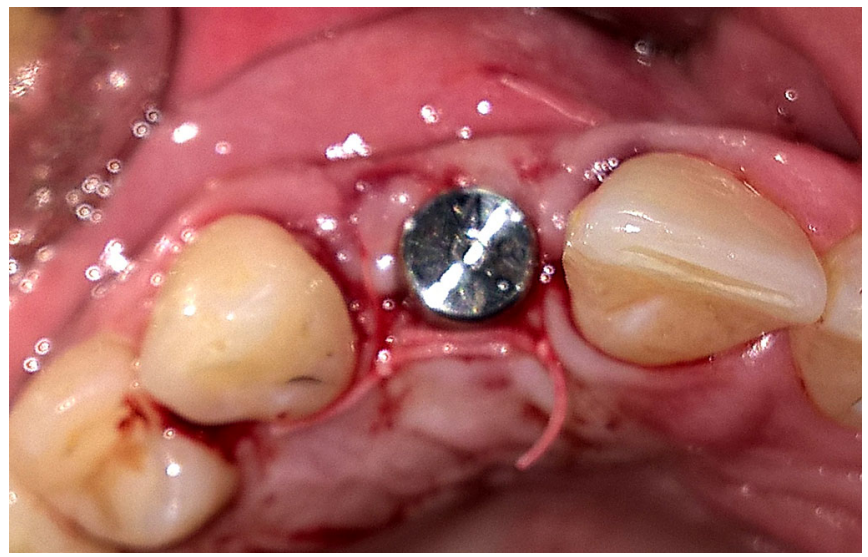

The following indicators have been traced out:

- Implantation area;

- Type of fixed restorations: single crowns, splinted crowns, bridge implant - implant, bridge implant - natural tooth;

- Crown height space;

- Decementation of FDP

All implants have been performed after a preliminary occlusal analysis, including examination of the occlusal scheme, teeth eruption, crown height space as well as inter-tooth and maxillomandibular relations. Reporting the available volume bone was determined by CT scans made in a central occlusion. The following equipment was applied - Planmeka Promax 3D (Planmeca Oy, Asentajankatu 6, FIN-00880 Helsinki, Finland). The crown height space was measured at the selected implant sites on the paraxial slices. The open-source software ImageJ 1.52i (National Institutes of Health, Bethesda, Maryland, USA) was used. The distance from the crestal bone of the alveolar ridge to the functional tubercles of the antagonist's teeth was reported (Fig 3). 
Fig. 3. Measurement of the crown height space by CBCT. The pre-selected implant sites are marked at the left, in the middle and right - vertical cuts in the implantation places. The distance is reported from the level of alveolar ridge to the functional tubercles of teeth antagonists.
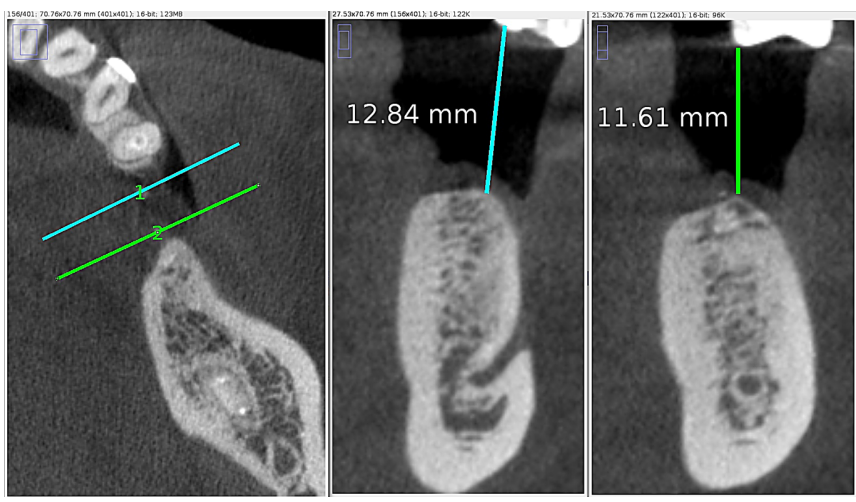

All restorations have been fixed with polymer polyacryl-urethane cement - (Dentotemp, Itena, 153, Victor Hugo Ave, 75116, Paris, France).

Postoperative checkups were performed respectively in the 1st, 3rd and 6th months, then once a year. An evaluation of the prosthesis restorations condition was carried out: cracks traces, porcelain fractures, detachment and presence of micro mobility. In cases of prosthetic restorations detachment, they were re-cemented with glass ionomer cement - Ketac Cem Plus (3M ESPE AG, ESPE Platz, 82229 Seefeld,) Germany (21).

The results statistical processing is consistent with the nature of the data and the nature of the phenomena being traced. Most of the indicators have no normal distribution, which necessitated the use of nonparametric methods of analysis. Descriptive methods of categorical and quantitative variables (mean, median, mode, standard deviation, minimum and maximum), cross tabulations, as well as hypothesis testing methods have been applied (KolmogorovSmirnov, Mann-Whitney and Kruskal-Wallis). Data processing was done with IBM SPSS Statistic 20 (Armonk, NY, 10504-1722, USA).

\section{RESULTS}

The results are based on data recorded by clinical examinations and software measurements. It is assumed for a zero hypothesis $\left(\mathrm{H}_{0}\right)$, that the crown height space does not affect the detachment of the adhesive retention between the implant platform and fixed prosthetic restorations.

In order to gain clear processing and results in interpretation, we combined the data in relation to the implantation areas into six groups: maxillary molars, maxillary premolars, anterior maxillary teeth, mandibular anterior teeth, mandibular premolars and mandibular molars. The implants distribution according to the place of implantation is as follows: maxillary molars $-32(12.3 \%)$, maxillary premolars - $48(18.4 \%)$, maxillary anterior teeth - 35 (13.4\%), mandibular anterior teeth - 20 (7.7\%), mandibular premolars - $29(11.1 \%)$ and mandibular molars - 97 $(37.2 \%)$.
- Type of prosthetic restoration. Single crowns were made in $112(42.9 \%)$ implants, splinted crowns in 51 $(19.5 \%)$, bridge "implant - implant" in $62(23.8 \%)$ - and bridge "implant - natural tooth" in 36 (13.8\%). Their retention was accomplished by cementation in all 261 cases.

- Crown height space. The data are summarized in several groups according to those accepted in scientific literature (22): insufficient restorative space - less than $6 \mathrm{~mm}$, minimum - from 6 to $8 \mathrm{~mm}$, optimally - from 8 to $12 \mathrm{~mm}$, large - from 12 to $15 \mathrm{~mm}$ as well as cases with a height of more than $15 \mathrm{~mm}$. The minimum reading value is $5.37 \mathrm{~mm}$, the maximum is $18 \mathrm{~mm}$ and means -10.786 at a standard deviation 2.987. The frequency of the analyzed cases has been presented in Table 1.

Table 1. Distribution of the detachment of fixed partial dentures regarding their type and crown height space (CHS). The incidence of this complication is highest when the height is less than $6 \mathrm{~mm}$. The total number of such cases was 18 , and in $1 / 3$ of these cases, we found detachment after the functional loading of dental implants within the first year.

Table 1. Crown Height Space distribution

\begin{tabular}{lcc}
\hline $\begin{array}{l}\text { Cronw height space } \\
\text { (mm) }\end{array}$ & $\begin{array}{c}\text { Frequency } \\
\text { (cases) }\end{array}$ & Percent \\
\hline less than $6 \mathrm{~mm}$ & $\mathbf{1 8}$ & $\mathbf{6 , 9 0 \%}$ \\
\hline from 6.0 to $8.0 \mathrm{~mm}$ & $\mathbf{2 1}$ & $\mathbf{8 , 0 0 \%}$ \\
\hline from 8.0 to $12.0 \mathrm{~mm}$ & $\mathbf{1 5 3}$ & $\mathbf{5 8 , 6 0 \%}$ \\
\hline from 12.0 to $15.0 \mathrm{~mm}$ & $\mathbf{2 9}$ & $\mathbf{1 1 , 1 0 \%}$ \\
\hline more than $15.0 \mathrm{~mm}$ & $\mathbf{4 0}$ & $\mathbf{1 5 , 3 0 \%}$ \\
\hline Total & $\mathbf{2 6 1}$ & $\mathbf{1 0 0 , 0 0 \%}$ \\
\hline
\end{tabular}

- Prosthesis detachment. This complication was found out in $5.7 \%$ of all follow-up cases. Figure 4 points out the distribution of cases with and without detachment depending on crown height space.

Regarding implant sites, data show that the most common adhesive bond loss of retention has been observed in the lower molar area (73.33\% of all cases). KruskalWallis test is usually used to check whether there are differences between groups. Statistically significant differences were ascertained depending on the site of implants performed and the detachment of prosthetic restoration $\gamma^{2}(5)=11.110, \mathrm{p}=0.049$.

The influence of the FPD type, at the onset of such complication, was followed by Kruskal-Wallis test. The data show that there are statistically significant differences between various types of prosthetic restorations $-\gamma^{2}(4)=8.147$, $\mathrm{p}=0.004$. The most common detachment was found to be in single crowns - 12 cases, followed by splinted crowns - 2, prosthesis in bridges of "implant - natural tooth" type - one case and never in bridges of the "implant - implant" type.

The influence of the crown height space on the loss of retention of the prosthetic restorations has been studied 
by Mann-Whitney test. The data revealed statistically significant differences between different groups: with detachment (mean rank 134.68) and those without (mean rank 70.70), $\mathrm{U}=940.500, \mathrm{p}<.0001$. In Table 2 , it is presented their distribution depending on the crown height space and type of implant supported restorations.

The data in Table 2 show an increased rate of decementation of implant-supported FPD when the height of the restorative space is minimal. This complication usually occurs when single crown restorations are used.

Table 2. Crown Height Space vs. FPD Type vs. Detachment of the FPD Crosstabulation (Count)

\begin{tabular}{|c|c|c|c|c|c|c|c|}
\hline \multirow{4}{*}{$\begin{array}{l}\text { Detachment of } \\
\text { the FPD }\end{array}$} & & & \multicolumn{4}{|c|}{ FPD Tyре } & \multirow{4}{*}{ Total } \\
\hline & & & Single & Splinted & Bridge & Bridge & \\
\hline & & & crown & crowns & Implant - & Implant - & \\
\hline & & & & & Implant & Natural tooth & \\
\hline \multirow[t]{6}{*}{ Not Detached } & Crown Height Space & less than $6 \mathrm{~mm}$ & 6 & 3 & 2 & 1 & 12 \\
\hline & & from 6.0 to $8.0 \mathrm{~mm}$ & 9 & 6 & 1 & 1 & 17 \\
\hline & & from 8.0 to $12.0 \mathrm{~mm}$ & 64 & 31 & 31 & 25 & 151 \\
\hline & & from 12.0 to $15.0 \mathrm{~mm}$ & 7 & 6 & 8 & 6 & 27 \\
\hline & & more than $15.0 \mathrm{~mm}$ & 14 & 3 & 20 & 2 & 39 \\
\hline & Total & & 100 & 49 & 62 & 35 & 246 \\
\hline \multirow[t]{6}{*}{ Detached } & Crown Height Space & less than $6 \mathrm{~mm}$ & 5 & 1 & 0 & 0 & 6 \\
\hline & & from 6.0 to $8.0 \mathrm{~mm}$ & 3 & 1 & 0 & 0 & 4 \\
\hline & & from 8.0 to $12.0 \mathrm{~mm}$ & 2 & 0 & 0 & 0 & 2 \\
\hline & & from 12.0 to $15.0 \mathrm{~mm}$ & 1 & 0 & 0 & 1 & 2 \\
\hline & & more than $15.0 \mathrm{~mm}$ & 1 & 0 & 0 & 0 & 1 \\
\hline & Total & & 12 & 2 & 0 & 1 & 15 \\
\hline \multirow[t]{6}{*}{ Total } & Crown Height Space & less than $6 \mathrm{~mm}$ & 11 & 4 & 2 & 1 & 18 \\
\hline & & from 6.0 to $8.0 \mathrm{~mm}$ & 12 & 7 & 1 & 1 & 21 \\
\hline & & from 8.0 to $12.0 \mathrm{~mm}$ & 66 & 31 & 31 & 25 & 153 \\
\hline & & from 12.0 to $15.0 \mathrm{~mm}$ & 8 & 6 & 8 & 7 & 29 \\
\hline & & more than $15.0 \mathrm{~mm}$ & 15 & 3 & 20 & 2 & 40 \\
\hline & Total & & 112 & 51 & 62 & 36 & 261 \\
\hline
\end{tabular}

The data in Table 2 show that the incidence of the detachment of the FDP increases while the crown height space decreases.

In the cases of detached restorations and replacement of cement with such higher retention resistance, we recorded a new detachment in only three cases, after a period of 8 to 12 months. All of them were with single crown restorations and limited restorative space - below $6.0 \mathrm{~mm}$. The definitive resolution to the arisen complication has been reached by making new screw-retained crowns.

\section{DISCUSSION}

The data from the conducted analyses give us reason to assume that the crown height space has a direct influence on the detachment occurrence of the implant supported FDP. On such grounds, we may reject the zero hypotheses $\left(\mathrm{H}_{\mathrm{o}}\right)$ and accept the alternative one.

The results of this study show that increased incidence of the detachment of implant-supported fixed partial dentures has been observed in crown height space below $8.0 \mathrm{~mm}$ (Fig 4). 
Fig. 4. Distribution of cases versus the crown height space. In the group with the loss of retention, the distance from the alveolar crest to the tubercles of the teeth antagonists is less than $8.0 \mathrm{~mm}$ in $66.66 \%$ of the patients studied.

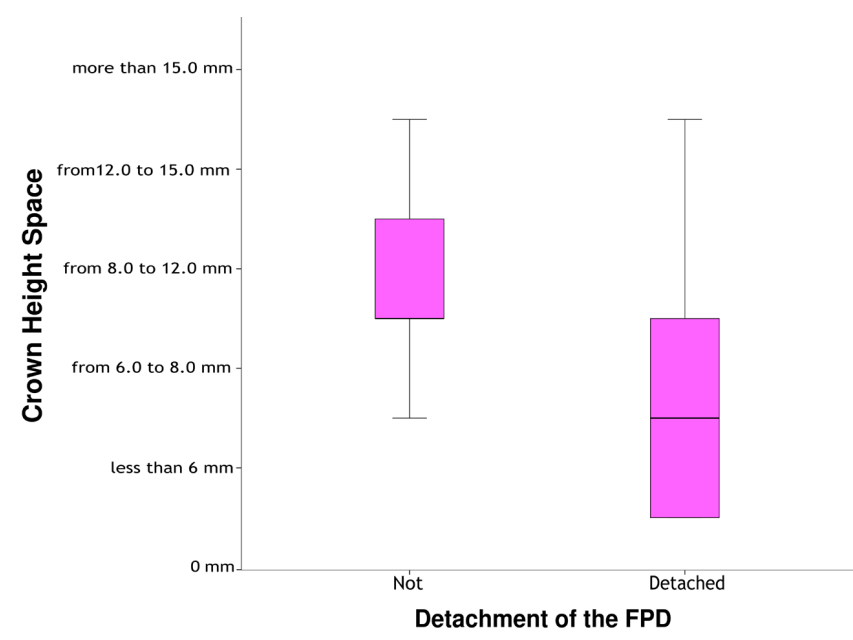

These data are similar to those depicted in other studies tracking the influence of this factor in cases of impaired retention of FPDs [23, 24]. The studies of Abbo B. et al. indicate that decreasing the abutment height by $1 \mathrm{~mm}$ significantly reduces the retention of the prosthetic restoration [25]. This tendency is most pronounced when the crown height space is below $6 \mathrm{~mm}$ and combined with the use of single crowns. Our data are in agreement with the research carried out by Rödiger et al. [26] where the influence of the abutment height and inclination over the detachment of the prosthetic restoration is monitored. The published data reveal that these two variables directly impacted long-term retention, regardless of the type of cement used - temporary or permanent [26].

On the other hand, the use of abutments with a larger diameter can significantly improve the retention of fixed restorations at a reduced height [27]. This approach cannot always be applied in clinical practice due to the anatomical constraints in the implantation area with respect to the available width, length and natural alveolar bone inclination.

A significantly lower incidence of the detachment of restorations with splinted crowns has been reported in conditions of reduced crown height space. Such data are consistent with the published data from the studies of Clelland $\mathrm{N}$ et al. [14] as well as Pellizzer EP et al. [28] showing that the incidence of biomechanical complications is lower in splinted crown prostheses compared to prosthetic restorations with similar single crowns under analogous other conditions. In this study, it may be assumed that the splinted crowns favour the distribution of functional stress by reducing stress in the area of the crest module and abutment, which is supported by the results of similar research [29].

The analysis of short and long-term studies showed fewer failures in adhesive retention of the fixed implant supported restorations compared to screw retained [1]. However, in case of a new loss of retention under conditions of reduced crown height space - less than $6 \mathrm{~mm}$, making a new screw retained prosthesis restoration turns out to be a good alternative.

Surface treatment of abutments by creating retention grooves or increasing the contact surface of abutment by means of sandblasting creates conditions to improve the retention of the prosthetic restoration [30]. These methods are most effective when applied with a simultaneous increase of the abutment height and the use of reinforced cement [31].

\section{CONCLUSION}

Although the data in the present study are limited, the results suggest that the reduced crown height space is a prerequisite for detachment of the implant supported FPDs. In such situations, the possibilities of subcrestal positioning of the implant platform and the use of abutments with minimal gingival height should be considered at the planning stage of prosthetic restoration. With this approach, there is a possibility of achieving improved retention due to the increased height of the implant abutment. If subcrestal implantation is impossible and the crown height space is below $6.0 \mathrm{~mm}$, an alternative approach is to use a screw-retained FPDs.

\section{Acknowledgements}

We would like to thank Assoc. Prof. Milena Stoycheva, Medical University - Sofia, Faculty of Public Health, for statistical data processing.

\section{REFERENCES:}

1. Jain JK, SethuramanR, Chauhan S, Javiya P, Srivastava S, Patel R, et al. Retention failures in cement- and screw-retained fixed restorations on dental implants in partially edentulous arches: A systematic review with metaanalysis. J Indian Prosthodont Soc. 2018 Jul-Sep;18(3):201-211. [PubMed] [Crossref]

2. Millen C, Brägger U, Wittneben JG. Influence of prosthesis type and retention mechanism on complications with fixed implant-supported prostheses: a systematic review applying multivariate analyses. Int J Oral Maxillofac Implants. 2015 Jan-Feb; 30(1): 110-24. [PubMed] [Crossref]

3. Lemos CA, de Souza Batista VE, Almeida DA, Santiago Junior JF, Verri FR, Pellizzer EP. Evaluation of cement-retained versus screw-retained implant-supported restorations for marginal bone loss: A systematic review and meta-analysis. J Prosthet Dent.
2016 Apr;115(4):419-27. [PubMed] [Crossref]

4. Wittneben JG, Buser D, Salvi GE, Bürgin W, Hicklin S, Brägger U. Complication and failure rates with implant-supported fixed dental prostheses and single crowns: a 10-year retrospective study. Clin Implant Dent Relat Res. 2014 Jun;16(3):356-64. [PubMed] [Crossref]

5. Ferreiroa A, Peñarrocha-Diago M, Pradíes G, Sola-Ruiz MF, Agustín- 
Panadero R. Cemented and screw-retained implant-supported single-tooth restorations in the molar mandibular region: A retrospective comparison study after an observation period of 1 to 4 years. J Clin Exp Dent. 2015 Feb 1;7(1):e89-94. [PubMed] [Crossref]

6. Mangano F, Macchi A, Caprioglio A, Sammons RL, Piattelli A, Mangano C. Survival and complication rates of fixed restorations supported by locking-taper implants: a prospective study with 1 to 10 years of follow-up. J Prosthodont. 2014 Aug;23(6):434-44. [PubMed] [Crossref]

7.Ülkü SZ, Acun Kaya F, Uysal E, Gulsun B. Clinical Evaluation of Complications in Implant-Supported Dentures: A 4-Year Retrospective Study. Med Sci Monit. 2017 Dec 27; 23:6137-6143. [PubMed] [Crossref]

8. Wang JH, Judge R, Bailey D. A 5Year Retrospective Assay of Implant Treatments and Complications in Private Practice: The Restorative Complications of Single and Short-Span Implant-Supported Fixed Prostheses. Int J Prosthodont. 2016 Sep-Oct;29(5): 435-44. [PubMed] [Crossref]

9. Misch CE. Dental Implant Prosthetics. 2nd ed. Maryland Heights, Mo: Mosby; 2015, p. 16567. [Crossref]

10. Misch CE, Goodacre CJ, Finley JM, Misch CM, Marinbach M, Dabrowsky T, et al. Consensus conference panel report: crown-height space guidelines for implant dentistry-part 2. Implant Dent. 2006 Jun;15(2):113-21. [PubMed] [Crossref]

11. Bresciano M, Schierano G, Manzella C, Screti A, Bignardi C, Preti G. Retention of luting agents on implant abutments of different height and taper. Clin Oral Implants Res. 2005 Oct;16(5):594-8. [PubMed] [Crossref]

12. Bernal G, Okamura M, Muñoz CA. The effeacts of abutment taper, length and cement type on resistance to dislodgement of cement-retained, implant-supported restorations. $J$ Prosthodont. 2003 Jun;12(2):111-5. [PubMed] [Crossref]

13. Saber FS, Abolfazli N, Nuroloyuni S, Khodabakhsh S, Bahrami M, Nahidi R, et al. Effect of Abutment Height on Retention of Single Cement-retained, Wide- and Nar- row-platform Implant-supported Restorations. J Dent Res Dent Clin Dent Prospects. 2012 Summer;6(3):98-102. [PubMed] [Crossref]

14.Clelland N, Chaudhry J, Rashid RG, McGlumphy E. Split-Mouth Comparison of Splinted and Nonsplinted Prostheses on Short Implants: 3-Year Results. Int J Oral Maxillofac Implants. 2016 Sep-Oct;31(5):113541. [PubMed] [Crossref]

15. Pellizzer EP, de Mello CC, Santiago Junior JF, de Souza Batista VE, de Faria Almeida DA, Verri FR. Analysis of the biomechanical behavior of short implants: The photo-elasticity method. Mater Sci Eng C Mater Biol Appl. 2015 Oct;55:187-92. [PubMed] [Crossref]

16. De Souza Batista VE, Verri FR, Lemos CAA, Cruz RS, Oliveira HFF, Gomes JML, et al. Should the restoration of adjacent implants be splinted or nonsplinted? A systematic review and meta-analysis. J Prosthet Dent. 2019 Jan;121(1):41-51. [PubMed] [Crossref]

17. Tsouknidas A, Giannopoulos D, Savvakis S, Michailidis N, Lympoudi E, Fytanidis D, et al. The Influence of Bone Quality on the Biomechanical Behavior of a Tooth-Implant Fixed Partial Denture: A Three-Dimensional Finite Element Analysis. Int J Oral Maxillofac Implants. 2016 Nov/ Dec;31(6):e143-e154. [PubMed] [Crossref]

18. Mamalis A, Markopoulou K, Kaloumenos K, Analitis A. Splinting osseointegrated implants and natural teeth in partially edentulous patients: a systematic review of the literature. $J$ Oral Implantol. 2012 Aug;38(4):42434. [PubMed] [Crossref]

19. Hita-Carrillo C, HernándezAliaga M, Calvo-Guirado JL. Toothimplant connection: a bibliographic review. Med Oral Patol Oral Cir Bucal. 2010 Mar 1;15(2):e387-94. [PubMed] [Crossref]

20. Michalakis KX, Calvani P, Hirayama H. Biomechanical considerations on tooth-implant supported fixed partial dentures. J Dent Biomech. 2012;3:1758736012462025. [PubMed] [Crossref]

21. Nematollahi F, Beyabanaki E, Alikhasi M. Cement Selection for Cement-Retained Implant-Supported
Prostheses: A Literature Review. J Prosthodont. 2016 Oct;25(7):599-606. [PubMed] [Crossref]

22. Resnik R, Misch CE. Avoiding Complications in Oral Implantology. St. Louis (Missouri 63043 USA), Elsevier Inc. c. 2018, Chapter 3: Treatment Planning Complications; p. 6768. [Crossref]

23. Cano-Batalla J, Soliva-Garriga J, Campillo-Funollet M, MunozViveros CA, Giner-Tarrida L. Influence of abutment height and surface roughness on in vitro retention of three luting agents. Int J Oral Maxillofac Implants. 2012 Jan-Feb; 27(1):36-41. [PubMed]

24. Al Hamad KQ, Al Rashdan BA, Abu-Sitta EH. The effects of height and surface roughness of abutments and the type of cement on bond strength of cement-retained implant restorations. Clin Oral Implants Res. 2011 Jun;22(6):638-44. [PubMed] [Crossref]

25. Abbo B, Razzoog ME, Vivas J, Sierraalta M. Resistance to Dislodgement of Zirconia Copings Cemented Onto Titanium Abutments of Different Heights. J Prosthet Dent. 2008 Jan; 99(1):25-9. [PubMed] [Crossref]

26. Rödiger M, Rinke S, EhretKleinau F, Pohlmeyer F, Lange K, Bürgers R, et al. Evaluation of removal forces of implant-supported zirconia copings depending on abutment geometry, luting agent and cleaning method during recementation. $J$ Adv Prosthodont. 2014;6:233-40. [PubMed] [Crossref]

27. Safari S, Hosseini Ghavam F, Amini P, Yaghmaei K. Effects of abutment diameter, luting agent type, and recementation on the retention of implant-supported CAD/CAM metal copings over short abutments. $J A d v$ Prosthodont. 2018 Feb;10(1):1-7. [PubMed] [Crossref]

28. Nissan J, Gross O, Ghelfan O, Priel I, Gross M, Chaushu G. The effect of splinting implant-supported restorations on stress distribution of different crown-implant ratios and crown height spaces. J Oral Maxillofac Surg. 2011 Dec;69(12):2990-4. [PubMed] [Crossref]

29. Lemos CAA, Verri FR, Santiago JF Júnior, Almeida DAF, Batista VES, Noritomi PY, et al. Retention System 
and Splinting on Morse Taper Implants in the Posterior Maxilla by 3D Finite Element Analysis. Braz Dent J. 2018 Jan-Feb;29(1):30-35. [PubMed] [Crossref]

30. Shrivastav M. Effect of surface treatments on the retention of implantsupported cement-retained bridge with short abutments: An in vitro compara- tive evaluation. J Indian Prosthodont Soc. 2018 Apr-Jun;18(2):154-60. [PubMed] [Crossref]

31. Rues $\mathrm{S}$, Fugina $\mathrm{M}$, Rammelsberg P, Kappel S. Cemented Single Crown Retention on Dental Implants: An In Vitro Study. Int J Prosthodont. 2017 Mar/Apr;30(2):133-135. [PubMed] [Crossref]

Please cite this article as: Kirov D, Stoichkov B. Influence of crown height space in cases of detachment of the implant supported fixed partial dentures: Retrospective clinical study. J of IMAB. 2020 Apr-Jun;26(2):3107-3113. DOI: https:// doi.org/10.5272/jimab.2020262.3107

Received: 25/06/2019; Published online: 30/04/2020

Corresponding author contact information:

Dimitar Kirov, assistant Professor, DDS, PhD

Department of Prosthetic Dentistry, Faculty of Dental Medicine, Medical University - Sofia,

1, St. Georgi Sofyiski Str., 1431 Sofia, Bulgaria.

e-mail: dimiterkirov@gmail.com 